
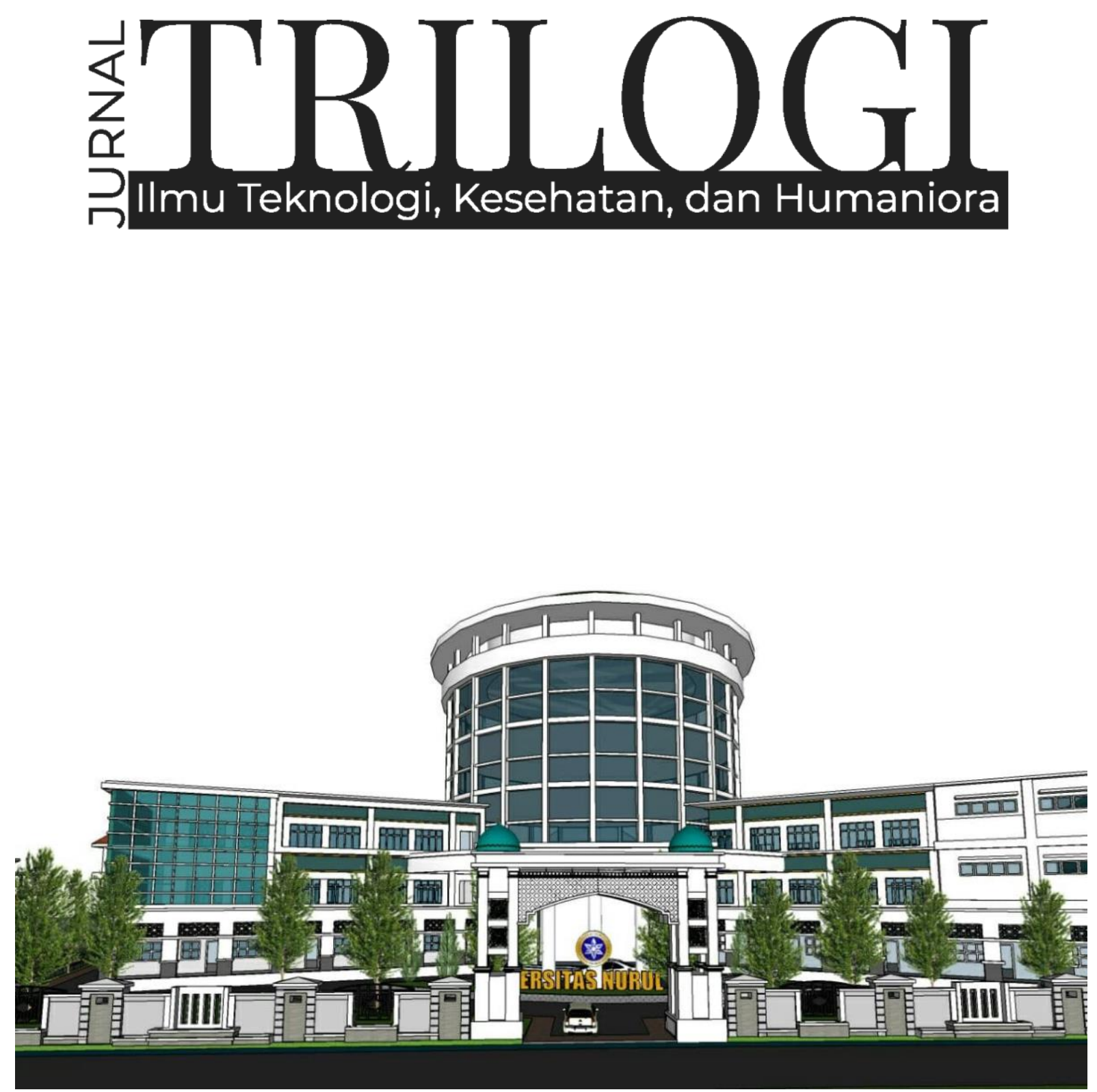

PENGEMBANGAN PENDIDIKAN DAN EKONOMI PESANTREN DI MASA PANDEMI COVID-19 


\section{犃BUOGI}

Vol. 2, No. 2, 2021

Editor in Chief

Achmad Fawaid, (SCOPUS ID: 57214837323)

\section{Managing Editors}

Hasan Baharun, (ID SCOPUS : 57200983602)

Sugiono Sugiono, (SCOPUS ID : 57199578160)

Ismail Marzuki, (SCOPUS ID: 57201500245

Subhan Rachman, (SCOPUS ID: 57192937912)

Nurul Huda, (SINTA ID: 6119615)

Syamsuri, (SINTA ID: 6116825)

Ridhatullah Assya'bani, (SINTA ID: 6200862)

\section{Peer Reviewers}

Miftahul Huda, (SINTA ID: 6171566), University of Antwerp, Belgium

Achmad Naufal Irsyadi, (SINTA ID: 6704870), Universitas Nurul Jadid, Indonesia

Gulpi Qorik Oktagalu P., (SINTA ID: 5982074) Universitas Nurul Jadid Probolinggo, Indonesia Hozairi, (SINTA ID: 166198), Universitas Islam Madura, Indonesia

Nur Hamid, (SINTA ID : 6744813), Univeristas Nurul Jadid Probolinggo, Indonesia Zainal Munir, (SINTA ID: 6672512), Universitas Nurul Jadid Probolinggo, Indonesia Sri Astutik Andayani, (SINTA ID: 6172559), Universitas Nurul Jadid Probolinggo, Indonesia Sukamto Sukamto, (SINTA ID: 5979034), Universitas Widya Gama Malang, Indonesia Deny Utomo, (SINTA ID: 6016108), Universitas Yudharta Pasuruan, Indonesia Fariz Alnizar, (SCOPUS ID: 6659824), UNUSIA Jakarta, Indonesia

Fuad Rahman, (SCOPUS ID: 57201474778), UIN Sulthan Thaha Saifuddin Jambi, Indonesia Saifuddin Zuhri Qudsy, (SCOPUS ID: 57213595165), UIN Sunan Kalijaga Yogyakarta, Indonesia Akhmad Anwar Dani, (SINTA ID: 14305), IAIN Surakarta, Indonesia

Maufur Maufur, (SINTA ID: 5989329), IAIN Kediri, Indonesia

Siti Mahmudah Noorhayati, (SINTA ID: 6726997), IAIN La Roiba Bogor, Indonesia Busro Busro, (SCOPUS ID: 57205022652), UIN Sunan Gunung Djati Bandung, Indonesia Akmal Mundiri, (SCOPUS ID: 57205059378), UNUJA Probolinggo, Indonesia

\section{Section Editor}

Ahmad Zubaidi, Universitas Nurul Jadid, Probolinggo, Indonesia 
TRILOGI: Jurnal IImu Teknologi, Kesehatan, dan Humaniora is a peer-reviewed journal, open-access journal which publishes original articles on various issues within technology, health, and social humanities, which include but are not limited to newrenewable energy, food-agriculture, health-pharmacy, transportation, informationcommunication technology, advanced-materials, maritime-infrastructre, social-artseducation, and religious studies based on academic and scientific research.

TRILOGI: Jurnal IImu Teknologi, Kesehatan, dan Humaniora seeks to publish a balanced mix of theoretical or empirical articles, case studies, review papers, comparative studies, exploratory papers, and book reviews. All accepted manuscripts will be possibly published both online and in printed forms.

Editorial Office:

TRILOGI: Jurnal IImu Teknologi, Kesehatan, dan Humaniora Lembaga Penerbitan, Penelitian, dan Pengabdian kepada Masyarakat (LP3M) Universitas Nurul Jadid, Paiton, Probolinggo, Jawa Timur, Indonesia 67291.

Phone: 088830 77077, Hp: 082318007953

Email: jurnal.trilogi@gmail.com

Website: https://ejournal.unuja.ac.id/index.php/trilogi/index 


\section{Tables of Content}

71-76

Pengaruh Metode Pembelajaran Daring dengan Aplikasi Google Classroom terhadap Hasil Belajar Siswa Madrasah Ibtidaiyah Nurul Mun'im Paiton Probolinggo

Feriska Listrianti, Lailatul Munawwaroh, Sayyidatul Arifa, Siti Aisyah

77-84

Inklusivitas dan Responsivitas Pesantren dalam Penanganan Pandemi Covid 19: Telaah Hidden Curriculum Pembelajaran di Pondok Pesantren Nurul Jadid

Zakiyah BZ, Uswatun Hasnah, Nafistur Rahmah

84-94

Integrasi Kurikulum Madrasah Diniyah dengan Lembaga Formal dalam Meningkatkan Mutu Lulusan di Sekolah Menengah Pertama (SMP) Nurul Jadid Paiton Probolinggo

Abdurrahman, Ika Fitri Anwar, Sofiya Mauliza, Nadya Afkarina

95-104

Some Issues on Time Deposit Financing: An Islamic Perspective on Mudharabah Agreement at Baitul Maal wa Tamwil (BMT) NU in Randuagung Lumajang

Saifuddin, Abdul Hafid, Hengki Wahyu Pratama

$105-110$

Analisis Pengembangan Potensi Ekonomi Keluarga melalui Unit Usaha Kapuk

Fahrudin, Iis Sa'diyah, Rizaldi Chandra Gunawan

111-117

Penguatan Ekonomi Pesantren melalui Pengembangan Ekonomi Masyarakat Pesisir: Pelajaran dari Pondok Pesantren Nurul Jadid Paiton Probolinggo

Achmad Febrianto, Muhammad Habibullah, Aksal Ilhamsyah

118-125

Prevensi Perilaku Konsumtif Persepektif Abraham Maslow dan Tri Logi Santri

Muhammad Syaiful Suib, Habibatur Rizkiyah, Fitria Nur Ain 
$126-136$

Manajemen Pengembangan Kurikulum Berorientasi pada Pembentukan Karakter

Moh Rifa'i, Fatimah Al Zahra, Abdurrahman Abdurrahman, Mukhlisin Saad

137-147

Home Industry, Kaderisasi, dan Santripreneur

Muh Hamzah, Aprilinda Dwi Kurniawati, Husnul Khotimah

148-157

Rancangan Pengelolaan Nirsampah Mandiri Skala Lembaga Pendidikan

Tirmidi, Eril Sinta Nuriyah, Rofi'ah

158-166

Parents' Knowledge and Commitment To Stimulate Child Development

Lailatul Fitriyah, Nurul Islamiyah, Auliya' Fatahillah

167-172

Implementasi Pembelajaran Akhlak Berbasis Multikultural pada Masa Pandemi di Madrasah Tsanawiyah Nurul Jadid Paiton Probolinggo

Abdullah, Yusrolana, Nur Laily

$173-183$

Implementasi Evaluasi Pembelajaran Daring (Online) melalui Home Visit

Moch Tohet, Moh. Bagus Abdillah, Adam Hakim Al Rizki

184-192

Efektivitas Pembelajaran Luring pada Mata Pelajaran Matematika selama Pandemi Covid-19

Zaenol Fajri, Sukron Junaidi, Hamdani Alfarisi 
P-ISSN: 2774-4574; E-ISSN: 2774-4582

TRILOGI, 2(2), Mei-Agustus 2021 (111-117) @2021 Lembaga Penerbitan, Penelitian, dan Pengabdian kepada Masyarakat (LP3M) Universitas Nurul Jadid Paiton Probolinggo

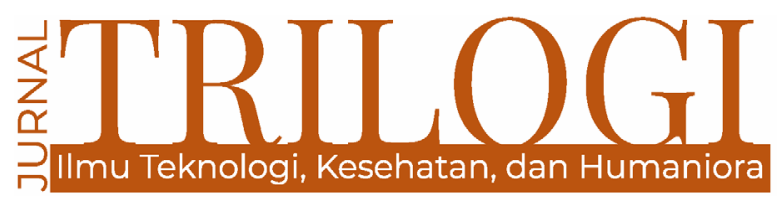

\title{
PENGUATAN EKONOMI PESANTREN MELALUI PENGEMBANGAN EKONOMI MASYARAKAT PESISIR: Pelajaran dari Pondok Pesantren Nurul Jadid Paiton Probolinggo
}

\author{
Achmad Febrianto ${ }^{1}$ \\ Universitas Nurul Jadid Paiton \\ febrismpnj@gmail.com \\ Muhammad Habibullah² \\ Universitas Nurul Jadid Paiton \\ bullahh544@gmail.com
}

\section{Aksal Ilhamsyah ${ }^{3}$}

Universitas Nurul Jadid Paiton

aksalilhamsyah08@gmail.com

\begin{abstract}
This study aims to analyze the contribution of the Nurul Jadid Islamic Boarding School through the empowerment of coastal Muslim communities through marine processed products. Through the phenomenological approach as a research method, this study tried to know the strategy and method of the Religus Islamic Boarding School in improving the economic economy of the Muslim coastal community. The results of the study showed (1) in formulating the pattern of coastal community empowerment, the principled Nurul Jadid Islamic Boarding School take two approaches, i.e. a social approach through increasing the ability of the community to be economically independent and an economical approach through the creation of economic management opportunities for the community, and (2) Islamic Boarding School Nurul Jadid has focused the empowerment of coastal economics through several stages, such as the order of social structures, economic equity, educational values of economic independence, community participation, and community involvement in regional development.
\end{abstract}

Keywords: Nurul Jadid Islamic Boarding School; Coastal Economy; Empowerment 


\begin{abstract}
Abstrak
Penelitian ini bertujuan menganalisis kontribusi Pondok Pesantren Nurul Jadid melalui pemberdayaan masyarakat Muslim pesisir melalui produk hasil olahan laut. Melalui pendekatan fenomenologi sebagai metode penelitian, penelitian ini berusaha mengetahui strategi dan metode pendekatan religus pondok pesantren dalam meningkatkan ekonomi masyarakat Muslim pesisir. Hasil penelitian memperlihatkan (1) Dalam merumuskan pola pemberdayaan masyarakat pesisir, Pesantren Nurul Jadid berprinsip pada dua pendekatan, yakni pendekatan sosial melalui peningkatan kemampuan masyarakat agar mandiri secara ekonomi dan pendekatan ekonomis melalui penciptaan peluang pengambangan ekonomi bagi masyarakat, dan (2) Pondok Pesantren Nurul Jadid telah memfokuskan pemberdayaan ekonomi pesisir melalui beberapa tahapan, misalnya tatanan struktur sosial, pemerataan ekonomi, edukasi nilai-nilai kemandirian ekonomi, partisipasi masyarakat, dan keterlibatan masyarakat pada pembangunan daerah.
\end{abstract}

Kata Kunci: Pesantren Nurul Jadid; ekonomi pesisir; pemberdayaan

\section{Pendahuluan}

Situasi perekonomian yang tidak kunjunga membaik pada masa pandemi membuat kemampuan dan keamanan dalam bekerja menjadi persoalan utama, dari kondisi tersebut banyaknya pusat perekonomian mengalami penurunan pemasukan terutama pada sektor rill. Akibatnya adalah pemberhentian sebagian karyawan yang bersifat sementara maupun permanen, banyaknya orang menggur menjadikan permasalahan kronis bagi negara ini, ini juga akan bereakibat pada lulusan muda negara ini yang bingung dalam menentukan nasip apalagi dengan tingginya tingkat kelulusan yang semakin bertambah dan ditambah adanya covid 19 yang tidak kian tuntas, hal tersebut akan menambah daftar pengguran di negara ini yang diakibatkan oleh sempitnya lapangan pekerjaan.

Dengan Pengetahuan yang dimiliki oleh para Iulusan muda merupakan salah satu instrumen dalam memenuhi kereteria pekerjaan, Pemberdayaan generasi muda adalah solusi yang tepat di masa ini, hal tersebut bisa dilakukan dengan menerapkan potensi yang ada dalam pengembangan ekonomi, potensi yang dimilik lulusan muda adalah potensi yang bisa menyesuaikan dengan perkembangan zaman, dengan memberikan pemahaman potensi ekonomi kreatif $^{1}$, dengan mengakat potensi lokal menjadi hal yang bernilai.

Rangsangan peningkatan potensi ekonomi kreatif pada masa pandemi ini juga dilakukan oleh pemuda yang berasal dari pondok pesantren, dimana dalam pandanganya mereka bisa membe-

1 Dedi Rianto Rahadi, "Analisis Sektor Usaha Kecil \& Menengah Menjadi Model Kewirausahaan Sosial Berbasis Ekonomi Kreatif," Jurnal Manajemen Dan Bisnis Indonesia 4, no. 2 (2017): 159-73. rikan sebuah pemahaman ekonomi kreatif yang terintegrasi dengan ilmu agama², sehingga pemahaman ekonomi yang berbasis agama bisa bisa menjadi solusi dimasa pandemi, seperti halnya pondok pesantren sebuah lembaga pendidikan yang mampu menggabungkan ilmu agama dengan ilmu sosial, pembelajaran multi indisipliner yang diterapkan diera moderen mampu mencetak para sarjana yang ahli dibeberapa bidang.

Dengan berkembangnya zaman pondok pesantren bukan lagi terfokus sebagai lembaga pendidikan Islam saja akan tetapi juga sebagai Lembaga Sosial yang memiliki peran strategis dalam membangun sebuah kemandirian bagi masyarakat, baik dari segi pendidikan maupun ekonomi yang berbasis kerakyatan. Sering kali masyarakat menyepelekan peran pesantren karena dianggap pesantren hanya mampu melahirkan para pemikir tradisional, religious atau da'i. hari ini peran pondok pesantren telah berkembang secara masif. Hal ini diyakini mampu menjadi solusi dalam mengatasi masalah tersebut, sekaligus menjadi alternatif dalam menghadapi tantangan ekonomi global yang menggeser sistem ekonomi yang telah berjalan, Indonesia yang kaya akan budaya dan penduduk sangat berpotensi dalam pengembangan ekonomi ${ }^{3}$.

Dalam mengembangkan ekonomi kreatif yang dilakukan pondok pesantren Nurul Jadid Paiton Probolinggo telah melakukan pemberdayaan masyakat muslim pesisir yang merupakan salah satu langkah yang tepat dalam melakukan pengembangan ekonomi. Masyarkat muslim pesisir dianggap sebagai masyarakat yang sangat

2 Kementrian Pariwisata, "Ekonomi Kreatif: Rencana Aksi Jangka Menengah 2015-2019," Jakarta, Kementrian Pariwisata Dan Ekonomi Kreatif, 2014.

3 Jimea Jurnal and IImiah Mea, "JIMEA | Jurnal Ilmiah MEA ( Manajemen , Ekonomi , Dan Akuntansi )" 5, no. 1 (2021): 1339-51. 
agamis, hal tersebut terpancar dari kegiatan keagamaan yang selalu rutin mereka lakukan, dan adanya peran pondok pesantren yang telah hadir ditengah tengah mereka untuk mencoba memanfaatkan potensi laut dengan pendekatan sosial dan agama agar potensi laut bisa lebih bernilai.

Dengan demikian, peneliti tertarik meneliti etika bisnis dengan pondok pesantren nurul jadid sebagai subjek dalam pemberdayaan ekonomi dan masyarakat pesisir sebagai subjeknya, Payung konsep pada penelitian ini adalah pendekatan sosial dan agama, karena dilihat dari pola hidup masyarakat pesisir yang sangat mensakralkan seorang tokoh agama yang berasal dari pondok pesantren serta peran pesantren dalam mengembangkan ekonomi masyarakat muslim pesisir

Empowerment atau dalam bahasa Indonesia disebut dengan pemberdayaan masyarakat yaitu sebuah konsep yang membangun ekonomi berbasis sosial yakni sebuah konsep yang lebih cenderung pada peran masnusia dalam berpartisipasi dibidang ekonomi atau disebut juga dengan people centered participatory ${ }^{4}$.

Pemikiran tentang empowering ini pada hakikatnya lebih luas yaitu pada membangun potensi manusia. Pemikiran ini mencoba untuk mendorong manusia agar tidak terbelenggu pada permainan politik ekonomi dimana kepentingan sektoral yang menjadi permasalahan sehingga tingkat kreatifitas manusia sangatlahh terbatas. Beberapa hasil penelitian yang dilakukan oleh IPAD (International Fund for Agriculture Development) mejelasakan bahwasanya peranan dari rakyat golongan menengah kebawah telah memberikan sumbangsih besar bagi pembangunan negara hal tersebut sangat berbanding terbalik dengan investasi pada sektor-sektor makro ${ }^{5}$, hal tersebut terceminkan pada meningkatktnya pendapatan ekonomi yang berdasarkan pada sektor lokal atau sektor mikro lebih efisien dalam membangun ekonomi bangsa.

Pertumbuhan ekonomi tersebut tidak membutuhkan banyak modal dalam hal tersebut sangat berpengaruh pada negara-negara yang sedang berkembang yang telah mengalami kekurangan devisa dan sangat lemah pada posisi pembayaran. Untuk mengkaji struktur pemberdayaan masyarakat dalam upaya peningkatan ekonomi, dapat

4 Iin Indarti and Dwiyadi Surya Wardana, "Metode Pemberdayaan Masyarakat Pesisir Melalui Penguatan Kelembagaan Di Wilayah Pesisir Kota Semarang," 2013.

5 Hagi Primadasa Juniarta, Edi Susilo, and Mimit Primyastanto, "Kajian Profil Kearifan Lokal Masyarakat Pesisir Pulau Gili Kecamatan Sumberasih Kabupaten Probolinggo Jawa Timur" 1, no. 1 (2013): 11-25. dikaji dari tiga, dan berikut penjelasanya:

Faktor enabling adalah usaha untuk terciptanya kondisi yang bisa meningkatkan potensi agar masyarakat lebih kreatif dalam menciptakan usaha. Asumsinya adalah pemahaman bahwa setiap orang, setiap masyarakat mempunyai potensi yang dapat dikembangkan, artinya tidak ada manusia yang terlahir tanpa memiliki kelebihan. Pemberdayaan yaitu upaya dalam memfasilitasi seseorang agar potensi atau bakat yang terpendam bisa bangkit dan menghasilkan, dengan cara dorongan inovatif serta membangun kreatifitas dibidang ekonomi

Faktor empowering yakni penguatan potensi rakyat dengan cara membangun manusia yang memiliki potensi agar peluang kerja lebih terbuka. Proses ini adalah proses yang paling utama dalam empowerment yakni peningkatan standarisasi mutu pendidikan dan kualitas kesehatan dan cakupan dalam pengembangan ekonomi seperti modal pengutan dibidang tekhnologi dan membangun fasilitas sarana layanan publik agar bisa dijangkau oleh seluruh eleman masyarakat. Maka dari itu diperlukan perencanaan yang terorganisisr secara matang agar cakupan pada peningkatan ekonomi bisa terfasilitasi.

Faktor protecting adalah faktor yang melindungi masyarakat golongan bawah atau masyarakat lemah, Yakni dengan peningkatan peran masyarakat dalam berpartisipasi hal tersebut dilakukan agar masyarakat bisa berperan dalam pengambilan keputusan yang berkaitan dengan kesejahteraan masyarakat dalam cakupan yang lebih luas ${ }^{6}$.

Pembangunan masyarakat diartikan sebagai bentuk yang dapat mendorong masyarakat untuk mandiri, oleh karena itu mereka dapat dengan mudah untuk mengindentifikasikan permasalahan yang dihadapi secara bersamaan serta keterbatasan akan kebutuhan hidupnya. pembangunan masyarakat diartikan sebagai kegiatan yang tersetruktur dalam menciptakan kemajuan ekonomi serta kemajuan dibidang social.

Sektor sosial adalah salah satu point terpenting dalam membangun ekonomi masyarakat dalam mewujudkan kesejahteraan, sektor ini harus didukung oleh beberapa organisasi yang handal dalam bidang peningkatan ekonomi agar menumbuhkan etos kerja yang baik dalam mencapi kesejahteraan ${ }^{7}$. Pembangunan masya-

\footnotetext{
6 Nendah Kurniasari, "MEMAKNAI PROGRAM PEMBERDAYAAN EKONOMI MASYARAKAT PESISIR" 6, no. 1 (2011): 7-13.

7 Prinsip-prinsip Penanggulangan Kemiskinan Di, "Prin-
} 
rakat (pedesaan) pada masa yang lalu mendasarkan pada azas pemerataan yang penerapannya diarahkan secara sektoral dan pada setiap desa. Pemerataan pembangunan pada masa lalu telah dicoba oleh pemerintah dengan tujuan agar pembangunan lebih merata meskipun anggaran yang tersedia sangatlah besar akan tetapi dengan luas daerah dan banyaknya desa sehingga kesediaan dana yang besar tersebut harus dibagi rata sehingga setiap desa mendapatkan dana yang relativ sangat minim, sehingga pemerataan pembngunan sulit untuk terwujudkan.

Paradigma dalam pemerataan pembangunan adalah langkah yang tepat dalam menanggulangi kemiskinan, akan tetapi dalam membangun perlu memperhatikan rambu-rambu agar pemabngunan yang ada tidak merusak tatakelolah yang ada didesa terutama pada daerah pesisir. Dalam meningkatkan pembangunan di daerah pesisir harus sesuai dengan tatakelolah yang ada agar nantinya bisa menjawab beberpa pertanyaan yang mendasar dari mereka dalam berpartisipasi untuk meningkatkan produktifitasnya, dan berikut beberapa pertanyaan yang sering ditanyakan oleh masyarakat pesisir:

- Bagaimana strategi dalam memotivasi masyarakat pesisir dalam meningkatkan produktifitas bagi masyarakat dengan pendapatan rendah.

- Bagaimana cara agar terciptanya aktifitas perekonimian yang melibatkan banyak setor di daerah pesisi.

- bagaimana cara dalam merancang program secara sistematis agar bisa dijadikan patokan oleh masyarakat pesisi.

- bagaimna langkah dalam mengintrgrasikan kebiasaan yang sudah membudaya dengan perencanaan matang dalam membangun perekonomian.

Masalah yang seringkali digaungkan oleh pemerintah setiap tahunya adalah cara dalam membangun masyarakat, akan tetapi terdapan inkonsiten pada cara dalam mebangun ekonomi pedesaan terutama daerah pesisir sehingga masyarakat selalu dilema dengan kebijakan tersebut. Dengan kondisi hari ini dimana telah terjadi pergeseran opini terkait peran pemerintah dalam mengembangkan ekonimi masyarakat, peran pemerintah bukan lagi sebagai provider akan tetapi lebih pada enabler. Pemerintah berperan sebagai enabler artinya pembangunan masyarakat dalam

sip-Prinsip Penanggulangan Kemiskinan Di Wilayah Pesisir Utara Jawa Tengah," 2015. meningkatkan kelayakan ekonomi berdasarkan kemampuan masyarakat secara mandiri bukan semata-mata pemerintah sebagai subjek utama dan lembaga pemerintah hanya sebagai fasilitas dalam pengembangan tersebut.

Dalam pidatonya Dirjen Bangde menjelaskan. Sebenarnya pembangunan masyarakat pesisir adalah suatu proses yang tidak bisa utuh artinya kebijakanya harus menyesuikan dengan perubahan situasi dan kondisi agar nantinya bisa berkelanjutan hal tersebut mencerminkan ide yang idial untuk dikembangkan secara terus menerus oleh karenanya dalam mengatur strategi yang bersifat dinamis perlu merancang managemen resiko agar masyarkat tidak tersesat pada rancangan pembanguann regonal ataupun pada pembangunan nasional ${ }^{8}$.

\section{Metode}

Penelitian ini mengulas etika sosial ekonomi dengan mencoba memperdalam kajian tentang pemberdayaan yang dilakukan oleh pondok pesantren kepada masyarakat muslim pesisir. Penelitian ini bertempat di pesisir Desa Karanganyar Kecamatan Paiton Kabupaten Probolinggo dan Pondok Pesantren Nurul Jadid Paiton Probolinggo, dalam penelitian ini dilaksanakan dalam kurun waktu 4 bulan yang dilaksanakan oleh tiga orang peneliti, satu selaku koordinator dan yang lain sebagai anggotanya. Penelitian ini menggunakan metode fenomenologi dengan teknik pengumpulan data berupa observasi lapangan yaitu melihat kejadiaan social secara langsung untuk bisa mendapatkan kesimpulan sementara tentang objek penelitian dan selanjutnya melakukan wawancara dalam wawancara peneliti mewawancarai beberapa informen yang terdiri dari pengurus badan usaha Pondok Pesantren Nurul Jadid dan masyrakat pesisir yang terlibat dalam pengembangan usaha milik Pondok Pesantren.Sebagai penguat landasan berfikir peneliti menambahkan beberapa referensi yang didapatkan dari buku-buku dan jurnal bereputasi yang berkaitan dengan pemberdayaan dan pembangunan ekonomi masyarakat ${ }^{9}$.

8 Kecamatan Tlanakan, Kabupaten Pamekasan, and Kecamatan Tlanakan, "Tinjauan Perilaku Konsumtif Masyarakat Pesisir Dalam Islam ( Studi Kasus Pada Masyarakat Pesisir Desa Bandaran, Kecamatan Tlanakan , Kabupaten Pamekasan )" 6, no. 2 (2019): 95-107.

9 Mukhamad Roni, "Interelasi Ekonomi Dan Bisnis Ekspor-Impor," n.d. 


\section{Hasil dan Pembahasan}

\section{Analisis Model Pemberdayaan Pondok Pesantren Nurul Jadid Paiton Probolinggo}

Upaya yang dilakukan oleh pondok pesantren Nurul Jadid dalam mengembangkan ekonomi kerakyatan atau pemberdayaan masyarakat adalah langkah yang tepat untuk membudayakan jiwa kewirausaan, salah satunya adalah proses inkubasi yang tidak berjalan dengan baik. Pendidikan dan pelatihan kewirausahaan dapat berjalan dengan baik, namun dari hasil pendidikan dan pelatihan tersbut tidak memberikan jaminan adanya keberlanjutan usaha setelah mereka lulus dari pendidikan pondok pesantren, adanya beberapa kendala yang mereka hadapi salah satunya adalah kendala permodalan dimana keterampilan yang mereka miliki tidak bisa dikembangkan

Sebenarnya permasalahan permodalan yang menajadi kendala utama santri dalam mengembangakan potensinya, pada hakikatnya hal tersebut bisa terselesaikan dengan cara melakukan pendekatan secara masif kepada masyarakat dengan mencoba untuk meningkatkan ekonomi dengan cara pemberdayan masyarkat dengan pemanfaatan potensi lokal. Gagsan ide tersebut telah dilakukan oleh Pondok Pesantren Nurul Jadid dimana pesantren memiliki peran yang sangat penting bagi masyarakat, oleh karnanya pendekatan pesantren dalam meningkatkan ekonomi masyarakat dengan cara pendekatan tokoh Agama serta beberapa pihak yang berperan didalamnya seperti, pengauh pesantren, santri, alumni Muhammad Idris Usman, 'Pesantren Sebagai Lembaga Pendidikan Islam (Sejarah Lahir, Sistem masyarakat serta peranan pemerintah dalam legalisali. Peranan dari beberapa sektor merupakan sebuah proses yang mengintegrasikan nilai-nilai agama pada peningkatan ekonomi lintas sektoral ${ }^{10}$.

Dalam upaya yang dilakukan pondok pesantren Nurul Jadid dalam merumuskan Perumusan pola pemberdayaan masyarakat pesisir haruslah berprinsip pada dua pendekatan, yang pertama adalah pendekattan dalam peningkatan kemampuan masyarakat secara mandiri dan terciptanya peluang pengambangan ekonomi bagi masyarakat. Dalam upaya yang dilakukan ini berdasarkan pada kemampuan masyarakat dalam mengembangkan ekonominya terutama bagi masyarakat pesisir yang telah memiliki potesi alam yang melimpah sehingga

10 Muhammad Idris Usman, "Pesantren Sebagai Lembaga Pendidikan Islam (Sejarah Lahir, Sistem Pendidikan, Dan Perkembangannya Masa Kini)," Jurnal Al-Hikmah 14, no. 1 (2013): 127-46. tujuan dari pondok pesantren dalam pemberdayaan ekonomi masyarakat pesisir bisa tercapat.

Pemberdayaan ini disebut dengan model pemberdayaan kelembagaan di mana pondok pesantren sebagai penggerak utama dalam mengembangkan potensi masyarakat sehingga peran dari Pemberdayaan kelembagaan mendorong dalam perubahan pada sektor tradisional di mana sebuah tradisi yang mengikat bisa digali potensinya menjadi potensi yang bermanfaat dan juga adanya peranan komunitas masyarakat pesisir dalam pengembangan potensi alam serta adanya pemahaman pasar dalam memasarkan produk olahan laut.

\section{Aktualisasi Nilai Islam dalam Pemberdayaan Masyarakat Muslim Pesisir Oleh Pondok Pesantren Nurul Jadid.}

Masyarakat muslim pesisir termasuk pada kelompok masyarakat dengen etos kerja yag sangat tinggi ini dibuktikan dengan adanya kegiatan yang bersifat terus-menerus semisal, pada bidang ekonomi hal tersebut terbukti dengan intesitas yang cukup tinggi dalam berkerja siang dan malam, dalam artrian lain masyarakat pesisir dikatan sepert masyarakat yang tidak pernah lelah dalam memenuhi kebutuhan sehari-hari, ini membuktikan bahwsanya etos kerja mereka sangat tinggi.

Dengan semangat juang yang tinggi dibidang ekonomi masyarakat pesisir juga tidak pernah meninggalkan kewajiban mereka dibidang agama. Dari penelitian ini, masyarakat pesisir dapat digolongkan ke dalam golongan masyrakat yang agamis, karena kegiatan keagamaan yang mereka lakukan tidak pernah seperti halnya ketika malam Jum'at mereka tidak melaut. Hal ini dipercayai bahwasanya malam jumat adalah malam yang membawa keberkahan, sehingga pada malam tersebut masyarkat pesisir melakukan ritual-ritual keagmaan yang membuat mereka menghentikan aktifitas melaut.

Kepedulian tinggi dalam bidang pendidikan yang dilakukan oleh masyarakat pesisir, ini terbukti dengan adanya dorongan pada para remaja untuk mengeyam pendidikan agama serta Alquran. Dengan kepedulian masyarkat pesisir akan pentingnya Agama membuat pondok pesantren Nurul Jadid yang bertempat di Kecamatan Paiton Kabupaten Probolinggo tertarik untuk mengembangkan ekonomi masyarakat pesisir dengan pendekatan agama, karena mayoritas masyarakat pesisir sangat mensakralkan sosok tokoh masyarakat seperti kyai dan para habaib.

Kesempatan ini dicoba dalam mengembangkan 
perkonomian masyarkat pesisir karena masyarakat pesisir didaerah kecamatan paiton memiliki potensi yang cukup kuat dalam pengembangan ekonomi untuk lebih baik oleh karena itu Pondok Pesantren Nurul Jadid mencoba untuk memberdayakan masyarakat mulim pesisir agar hasil sumberdaya laut bisa menjadi bahan olahan yang lebih bermanfaat, karena banyaknya kasus yang beredar masyarakat pesisir di Kecamtan Paiton terbelenggu oleh sistem yang sudah membudaya yakni adanya campur tangan dari pihak tengkulak sehingga untuk mengembangkan kreatifitas dalam bentuk olahan hasil laut sangatlah susah.

Pemberdayaan masyarakat yang dilakukan oleh pondok pesantren Nurul Jadid yaitu mengembangkan potensi, memberdayakan masyarakat dan memotivasi agar mandiri dalam bidang usaha serta pemahaman marketing dalam pemasaran produk hasil olahan laut. Pemberdayaan yang dilakukan oleh pondok pesantren Nurul Jadid kepada masyarakat muslim pesisir diharapkan mampu untuk mengelolah sumberdaya laut secara maksimal hal tersebut agar program pemberdayaan ini bisa berkelanjutan sampai anak cucu mereka. Maka dengan adanya program yang berkelanjutan kemandirian ekonomi masyarakat muslim pesisir akan terjamin dan bisa dikembangkan sesuai dengan permintaan pasar,

Akan tetapi perlu juga perlu melihat kapasitas alam yang ada sehingga dalam mengembangkan ekonomi masyarakat muslim pesisir di Kecamatan Paiton juga harus menjaga kelestarian alam karena konsep utama dalam Islam adalah maslahah yang mana pemanfaatan sumberdaya bukan semata-mata sebagai tujuan dalam mencapai kepuasan tetapi kesejahteraan bersama dengan menjaga kondisi alam adalah tujuan dari pengajaran aktualissa Islam sebagai agama yang dapat diterima oleh seluruh kalangan masyarakat ${ }^{11}$, dalam mengembangkan ekonomi masyrarakat peisir Pondok Pesantren Nurul Jadid menjelaskan beberapa Upaya yang dilakukan, dan berikut penjelasanya:

1. pemberdayaan masyarakat di kecamatan Paiton bisa dilihat dari tatanan struktur sosial mereka sehingga upaya yang dilakukan oleh Pondok Nurul Jadid dalah dengan mengombinasikan peranan struktur sosial yang agamis dengan peran pesantren dalam dunia dakwah.

2. Upaya dalam pemberdayaan adalah suatu proses dalam pemerataan ekonomi dimana proses ini memberikan peluang bagi masyarakat tidak mamapu untuk mengembangkan ekonominya

3. Pemberdayaan yang dilakukan oleh Pondok Pesantren Nurul Jadid sebagai bentuk edukasi yang bertujuan agar masyarakat lebih mandiri dalam menjalankan roda perokonomian dan tidak bergantuang pada lembaga manapun.

4. Adanya kolaborasi antara pondok pesantren dan seluruh masyarakat sehingga dalam mencapai kesusksesan diperlukan partisipasi yang kuat dari kedua belah pihak.

5. Upaya yang terakhir adalah keterlibatan masyarakat pada pembangunan daerah di mana peran masyarakat sangat fital sehingga perlu adany upaya dan dorongan agar pembanguan daerah melibatkan potensi lokal yang dimiliki oleh masyarakat. Dari penjelasan dan pemetaan diatas adalah nilai-nilai aktualisasi Pondok Pesantren Nurul Jadid yang bersifat Agamis dalam memberdayakan ekonomi masyarakat muslim pesisi

\section{Kesimpulan}

Dalam upaya yang dilakukan pondok pesantren Nurul Jadid dalam merumuskan Perumusan pola pemberdayaan masyarakat pesisir haruslah berprinsip pada dua pendekatan, yang pertama adalah pendekatan dalam peningkatan kemampuan masyarakat secara mandiri dan terciptanya peluang pengambangan ekonomi bagi masyarakat. Pemberdayaan ini disebut dengan model pemberdayaan kelembagaan dimana pondok pesantren sebagai penggerak utama dalam mengembangkan potensi masyarakat sehingga peran dari Pemberdayaan kelembagaan mendorong dalam perubahan pada sektor tradisional dimana sebuah tradisi yang mengikat bisa digali potensinya menjadi potensi yang bermanfaat dan juga adanya peranan komunitas masyarakat pesisir dalam pengembangan potensi alam serta adanya pemahaman pasar dalam memasarkan produk olahan laut dalam mengembangkan ekonomi masyrarakat peisir Pondok Pesantren Nurul Jadid menjelaskan beberapa Upaya yang dilakukan seperti Melihat tatanan struktur sosial, pemerataan ekonomi, Edukasi Nilai-nilai kemandirian ekonomi, Partisipasi Masyarakat, dan Keterlibatan masyarakat pada pembangunan daerah.

11 Zamakhsyari Dhofier, Tradisi Pesantren: Studi Tentang Pandangan Hidup Kyai (Lembaga Penelitian, Pendidikan, dan Penerangan Ekonomi dan Sosial, 1982). 


\section{Daftar Pustaka}

Amalia, Nur Fadlin, Umi Dayati, and Zulkarnian Nasution. "Peran Agen Perubahan Dalam Pelaksanaan Program Pemberdayaan Masyarakat Pesisir Pantai Bajulmati Kabupaten Malang." Jurnal Pendidikan: Teori, Penelitian, Dan Pengembangan 2, no. 11 (2017): 1572-76. http://journal.um.ac. id/index.php/jptpp/article/view/10249.

Dhofier, Zamakhsyari. Tradisi Pesantren: Studi Tentang Pandangan Hidup Kyai. Lembaga Penelitian, Pendidikan, dan Penerangan Ekonomi dan Sosial, 1982.

Di, Prinsip-prinsip Penanggulangan Kemiskinan. "Prinsip-Prinsip Penanggulangan Kemiskinan Di Wilayah Pesisir Utara Jawa Tengah," 2015.

Eko-syariah, Perspektif, and Moh Mufid. "FIKIH MANGROVE : FORMULASI FIKIH LINGKUNGAN PESISIR" 7, no. April 2017 (n.d.).

Indarti, Iin, and Dwiyadi Surya Wardana. "Metode Pemberdayaan Masyarakat Pesisir Melalui Penguatan Kelembagaan Di Wilayah Pesisir Kota Semarang," 2013.

Juniarta, Hagi Primadasa, Edi Susilo, and Mimit Primyastanto. "Kajian Profil Kearifan Lokal Masyarakat Pesisir Pulau Gili Kecamatan Sumberasih Kabupaten Probolinggo Jawa Timur" 1, no. 1 (2013): 11-25.

Jurnal, Jimea, and Ilmiah Mea. "JIMEA | Jurnal Ilmiah MEA ( Manajemen, Ekonomi , Dan Akuntansi )" 5, no. 1 (2021): 1339-51.

Konsep, Identifikasi, Al- Udud Al, Murakkabah Abdul, Ilma Mahdiya, Identifikasi Konsep Al- Uqud Al-murakkabah, D A N Al- Uqud, Al- Muta Addidah, Dalam Muamalah, Abdul Wahab, and Ilma Mahdiya. "PENDAHULUAN Perbankan Islam Sekarang Telah Menjadi Istilah Yang Terkenal Luas Baik Di Dunia Muslim Maupun Di Dunia Barat . Istilah Tersebut Mewakili Suatu Bentuk Perbankan Dan Pembiayaan Yang Berusaha Menyediakan Layanan-Layanan Bebas Bunga Kepada Para Na," n.d., 1-16.

Kurniasari, Nendah. "MEMAKNAI PROGRAM PEMBERDAYAAN EKONOMI MASYARAKAT PESISIR" 6, no. 1 (2011): 7-13.
Murdayanti, Yunika, and Susi Indriani. "PkM Kopontren Daarul Rahman Cipedak Jagakarsa Jakarta Selatan Melalui Kewirausahaan Syariah Berbasis Smartphone." JURNAL PENGABDIAN KEPADA MASYARAKAT (AbdiMas) 1, no. 2 (2019): 87-103. https://doi.org/10.30871/ abdimas.v1i2.1668.

"No Title" 2, no. 1 (2021): 115-20.

Pariwisata, Kementrian. "Ekonomi Kreatif: Rencana Aksi Jangka Menengah 20152019." Jakarta, Kementrian Pariwisata Dan Ekonomi Kreatif, 2014.

Podungge, Rulyjanto. "Potensi BMT (Baitul Mal Wattamwil) Pesantren Guna Menggerakkan Ekonomi Syari'ah Di Masyarakat." Al-Mizan 10, no. 1 (2014): 48-68.

Puji, Ekananda, and Indah Lestari. "DENGAN PERILAKU KONSUMTIF REMAJA DI PESISIR KECAMATAN REMBANG TAHUN 2015 SKRIPSI," 2015.

Rahadi, Dedi Rianto. "Analisis Sektor Usaha Kecil \& Menengah Menjadi Model Kewirausahaan Sosial Berbasis Ekonomi Kreatif." Jurnal Manajemen Dan Bisnis Indonesia 4, no. 2 (2017): 159-73.

Rimbawan, Yoyok. "Pesantren Dan Ekonomi: Kajian Pemberdayaan Ekonomi Pesantren Darul Falah Bendo Mungal Krian Sidoarjo Jawa Timur," 2012.

Roni, Mukhamad. "Interelasi Ekonomi Dan Bisnis Ekspor-Impor," n.d.

Syraiah, Fakultas, Ekonomi Islam, Iain Syekh, Nurjati Cirebon, Isu-isu Kelautan Dari, Kemiskinan Hingga, Bajak Laut, and Pustaka Pelajar. "No Title," n.d., 144-66.

Tlanakan, Kecamatan, Kabupaten Pamekasan, and Kecamatan Tlanakan. "Tinjauan Perilaku Konsumtif Masyarakat Pesisir Dalam Islam ( Studi Kasus Pada Masyarakat Pesisir Desa Bandaran , Kecamatan Tlanakan , Kabupaten Pamekasan )" 6, no. 2 (2019): 95-107.

Usman, Muhammad Idris. "Pesantren Sebagai Lembaga Pendidikan Islam (Sejarah Lahir, Sistem Pendidikan, Dan Perkembangannya Masa Kini)." Jurnal Al-Hikmah 14, no. 1 (2013): 127-46. 